\title{
The Image of Australia: A Case Study on the Mental Maps of Turkish Immigrants in Sydney
}

\author{
Cemil Gökten ${ }^{1} \&$ İlkay Südaş \\ ${ }^{1}$ Macquarie University, Sydney, Australia \\ ${ }^{2}$ Department of Geography, Ege University, Izmir, Turkey \\ Correspondence: İlkay Südaş, Department of Geography, Ege University, Izmir, Turkey. Tel: 90-232-311-3940. \\ E-mail: ilkaysudas@gmail.com
}

$\begin{array}{lc}\text { Received: February 20, } 2014 & \text { Accepted: March 11, } 2014 \quad \text { Online Published: May 3, } 2014 \\ \text { doi:10.5539/jgg.v6n2p82 } & \text { URL: http://dx.doi.org/10.5539/jgg.v6n2p82 }\end{array}$

\begin{abstract}
In this study, mental representations of Australia were examined through mental maps in case of Turkish immigrants living in Sydney. The survey is based on 53 mental maps of Australia drawn by Turkish immigrants who reside in Sydney. The participants were asked to list the connotations about Australia, draw a sketch map of the continent and finally fill in an outline Australian map. A prominent difference between these two types of mental maps was in the number and in the categories (place names, natural-geographic elements and symbols) of the components that were displayed by the participants. On the other hand, a comparison of our study with similar academic works conducted from a European example shows that connotations on Australia are predominantly referred to the natural characteristics of the continent. This could be related to the physical isolation Australia as a continent and also to the political indifference tendencies of the urbanized part of the society because of a high living standard.
\end{abstract}

Keywords: Australia, mental maps, Turkish immigrants, representation

\section{Introduction}

Mental (or cognitive) maps reflect the environmental image of individuals which form over time and can reflect perceptions of individuals at different scales. This can differ from being a single street view to a whole city and as well as from a country to a continental scale. Studied within various disciplines such as environmental psychology, geography and urban planning, mental maps are unique ways to visualize subjective spatial knowledge of individuals. Downs and Stea (1973) define these maps as "a construct which encompasses cognitive processes which enable people to acquire, code, store, recall and manipulate information about the nature of their spatial environment" (Saarinen, 1987). According to Milgram (1972) they are the main tools that are used to identify spatial images and the difference between physical and subjective environments. On the other hand, Tuan (1975) refers to a term mental map as a special type of image which is even less directly related to sensory experience and states that mental maps, like real maps, are a means to structure and store knowledge.

It is known that mental mapping researches have been conducted in different environmental units at various scales (i.e., Lynch, 1960; Johnston, 1972; Saarinen, 1988; Andersen \& Maude, 1994) for different purposes such as measuring the geographical competencies (Anderssen, 1997; Südaş \& Gökten, 2012), understanding image of cities (Lynch, 1960; Milgram, 1972; Francescato \& Mebane, 1973; Göregenli, 1985), countries, continents and the world (i.e., Saarinen, 1987). These studies were conducted among different sample groups however mental mapping studies especially on immigrant groups are not so common in the literature (i.e., Fuller \& Chapman, 1974). Fuller and Chapman (1974), in their early work relating migration and mental mapping, stated that "previous mental research has concentrated on people from the same source area". However, there are a few researches about the spatial images of immigrant groups. Clark (1977), for instance, focused on the image of the German city of Cologne among the Turkish immigrants. Orleans (1973) studied the image of Los Angeles, comparing different social groups one of which was a Spanish speaking minority who were not the native of the city. His research revealed that they have a much limited image of the city then the other groups. On the other hand, using outline blank maps of USA, Fuller and Chapman (1974) tried to map the most favourable and unfavourable areas by different migrant students. Basing on mental maps, our study will focus on the image and representations of Australia among Turkish immigrants who live in Sydney. 
Australia holds a unique location as an island, an "isolated" continent set in the southern hemisphere. The country that was colonized by the British just over 200 years ago retains many of the symbols, traditions, and images of that heritage (Clark, 1986) and Australia is, in many ways, a European country in the "wrong hemisphere" (Fisher \& Sonn, 2002). This study was conducted in order to identify the images of Australia, as a far away part of "European Cultural Influence" area. It has a multicultural population of 21.5 million including diverse groups of immigrants. Almost a quarter (24.6 per cent) of Australia's population was born overseas and 43.1 per cent of people have at least one overseas-born parent, mostly from United Kingdom (20.8\%), New Zealand (9.1\%), China (6.0\%) and India (5.6\%). Where Greece and Italy constitute a big percentage of heritage, parts of Middle East and South-East Asia also among other regions where Australian's declare as birth place or cultural heritage. Our studies' target group of Australians who have a Turkish background is relatively small; the latest census in 2011 recorded 32.845 Turkey-born people in Australia, an increase of 7.7 per cent from 2006. The location of our study and sample group Sydney, New South Wales has the second most Turkish population in the country with 12.977 people. The median age of the Turkey-born citizens in 2011 was 45 and the census showed a 51.5 per cent (16.923) male to a 48.5 per cent (15.922) female ratio among the population.

\section{Aim and Methodology}

A survey was conducted in order to identify the images of Australia through mental maps of Turkish immigrants. Understanding mental maps held by immigrants is important because they can be used to identify how the immigrated country is perceived. Connotations are also important to understand the images of a country; therefore, connotations of Australia were also asked to the participants.

Besides understanding the images and representations of Australia, it is also aimed in our study to understand whether mental maps of the same country differ between when an outline map is given to be filled-in by the participant (referred to as Type 1 maps) and when the participant is given a blank paper and is completely free whilst drawing (referred to as Type 2 maps). Thus, it is also questioned in this study if the technique of mental mapping is affective on the results.

The sample group consists of 28 Turkish immigrants who live in Sydney, Australia. A blank A4 sized paper sheet was given to the each participant and they were asked to draw a map of Australia and show all the details they can. Afterwards, they were given an outline map of Australia to be filled in with all the characteristics of continent that they know. The participants filled in a questionnaire with basic socio-demographic features. $25 \%$ of the participants was women (7) and $75 \%$ was men (21). The average age was 30,7 years. Average length of stay in Australia was 11,07 years. $42.9 \%$ of the participants were students, $32.1 \%$ workers, $10.7 \%$ commercial enterprisers and 10,7 others (1 participant did not respond).

In order to determine the representations of Australia, a technique named "constellation of connotations", developed by Moles (Bilgin 1995) was utilized and the participants were asked to list the first five things that the word "Australia" reminds them of. The connotations were classified and 5 main categories were derived about the meaning of Australia. Based on these categories, constellation of connotation of Australia was prepared (Figure 1). The components (names, symbols etc.) of the maps were also classified and shown on a map in order to see the differences between the two different mapping styles. Totally 53 maps were analysed (27 of the maps were Type 1 maps and 26 of them were Type 2 maps).

\section{Findings: Mental Maps and Connotations of Australia}

The mental maps analyzed basically include three types of components: (1) place names (cities and states), (2) natural and geographical characteristics and (3) symbols (Tables 1-5). The classification of components can be seen in the Table 1. Place names include mostly the big cities of the country while natural geographical characteristics include the elements such as deserts, gulfs, mountains and other geographical features. Among symbols of Australia, on the other hand, elements and icons such as the Aboriginal Flag, Aborigine people, "Aussie" flag, boomerang, dingo, surfing, sharks, kangaroo, koala and the architectural symbols like the Opera House and the Harbour Bridge were shown (Figures 1-6).

There is a striking difference of components according to the technique of mental mapping. The average number of place names and geographical characteristics are distinctly high on the filled-in outline maps when compared to the freely drawn maps. The average number of components per participant is 14,1 on the Type 1 maps while this number decreases to 9,5 in the Type 2 maps However, the number of the symbols (icons, scrawls etc.) on the Type 2 maps is very high compared to the Type 1 (57 times vs. 6 times) (Figure 7).

The distribution of the place names on an Australian map indicates that the Type 1 maps are richer in aspect of components and there is intensification on the east and south east part of the continent. The components on the 
maps become more indistinct on the result from the Type 2 maps. In both maps, Tasmania is shown relatively more frequently (Figure 8).

Eden (2004) asserts that a cognitive map has several structural properties and the shape is one of them to be considered in analysing the mental maps. Göregenli (2010) suggests different shapes of mental maps, those include bloc, graphical, symbolic, serial and dot styles. Majority of the Type 2 maps that were derived from this study is in graphic style and the proportion of the symbolic maps is very low (1.9\%). Regardless gender, most of the participants draw graphic style maps which refer to a cartographic-like maps rather than symbols and/or icons.

Maps of the participants who have lived in Australia longer than 10 years has a more realistic drawing of the especially state borders when compared to those whose length of stay in Australia in shorter. On the maps of the participants who have lived in Australia relatively shorter period, the borders of the states were shown less and/or incorrect.

209 connotations from participants were counted and classified and five main categories were derived which can be seen in Table 6. Australia is mostly represented by its natural characteristics, cultural symbols and with the lifestyle it offers. Figure 9 was prepared based on the frequencies of the connotations about Australia and exhibited in accordance with their distance from the central concept of "Australia". The connotations nearest the concept are the ones related to the natural characteristics of the continent (82 times), the most peripheral ones on the other hand, are about political and economic characteristics (only 14 times).

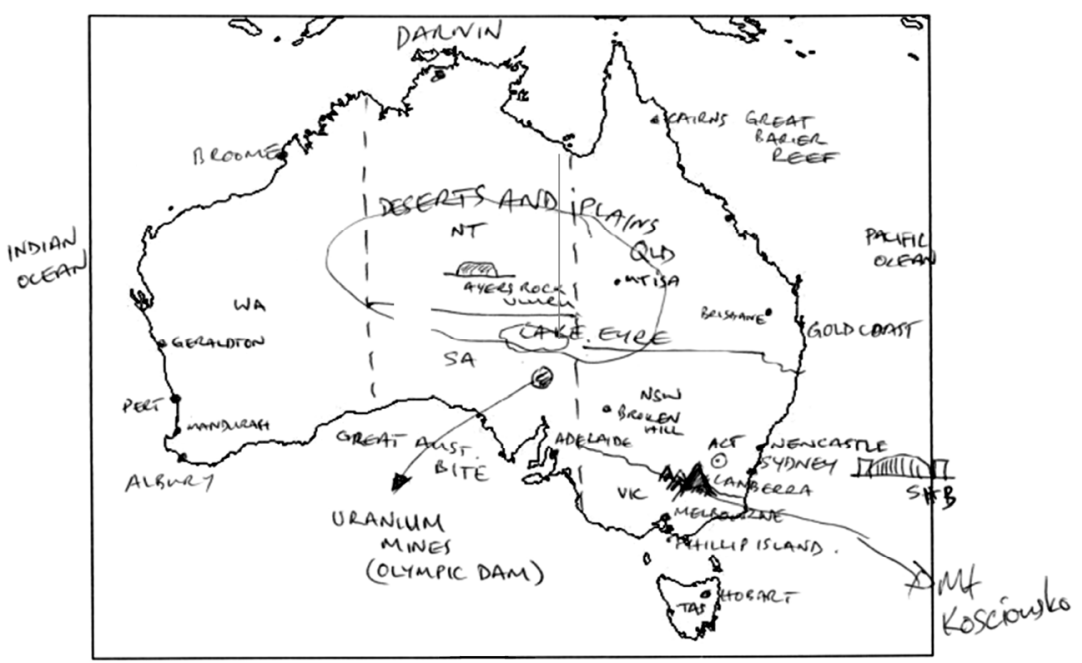

Figure 1. An outline map filled by a participant, including symbolic elements such as Uluru and Harbour Bridge

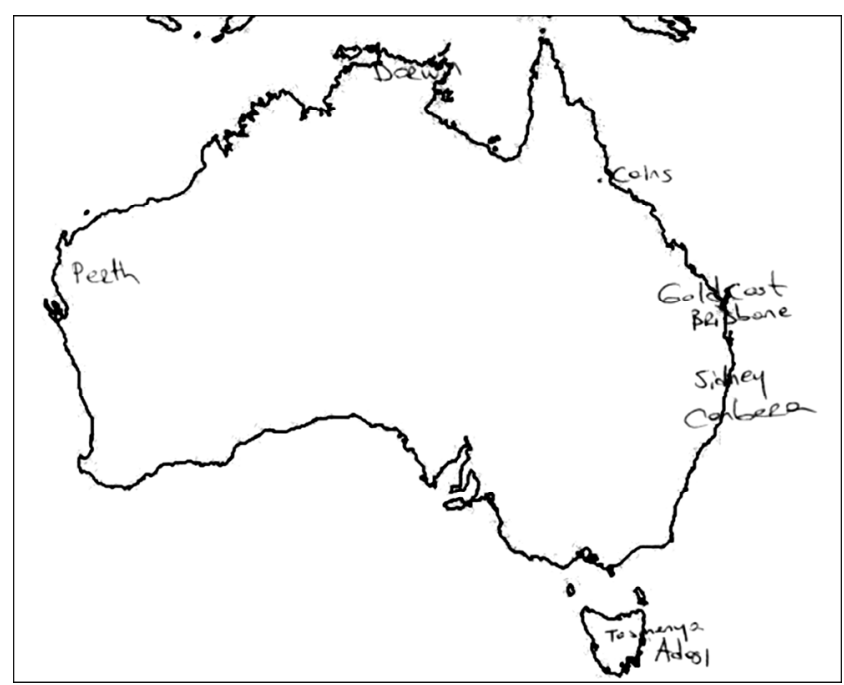

Figure 2. An outline map of Australia without symbols 
Table 1. Components shown on the maps

\begin{tabular}{|c|c|c|}
\hline \multirow[t]{2}{*}{ Place Names } & Cities & $\begin{array}{l}\text { Adelaide, Albury, Alice Springs, Auckland, Brisbane, Broken Hill, } \\
\text { Broom, Cairns, Canberra, Coffs Harbour, Darwin, Geraldton, Gold Coast, } \\
\text { Griffith, Hobart, Mandurah, Marsfield, Melbourne, Newcastle, Nimbin, } \\
\text { Perth, Port Douglas, Port Stephen, Sydney, Townsville, Wagga Wagga, } \\
\text { Wellington, Wollongong, Yamba }\end{array}$ \\
\hline & States & $\begin{array}{l}\text { Australian Capital Territory, New South Wales, Northern Territory, } \\
\text { Queensland, South Australia, Tasmania, Victoria, Western Australia }\end{array}$ \\
\hline \multicolumn{2}{|l|}{$\begin{array}{l}\text { Natural /geographical } \\
\text { characteristics }\end{array}$} & $\begin{array}{l}\text { Capeyork Peninsula, Bass Strait, Blue Mountains, Byron Bay, Christmas } \\
\text { Islands, Darling River, Desert, Great Australian Bite, Great Barrier Reef, } \\
\text { Gulf of Carpenter, Hunter Valley, Indian Ocean, Lake Eyre, Lane Cove, } \\
\text { Mt. Kosciuszko, Pacific Ocean, Phillip Island, Tasman Sea, Uluru-Ayers } \\
\text { Rock, Uranium mines, Wolf Creek crater }\end{array}$ \\
\hline Symbols & & $\begin{array}{l}\text { Aboriginal Flag, Aborigine, Apple, Aussi Flag, Boomerang, Dingo, } \\
\text { Floods, Forest, Gay Couples, Grape, Harbour Bridge, Jaws/sharks, } \\
\text { Kangaroo, Kangaroo Island, Koala, Meat, Money/AUD, Nicole Kidman, } \\
\text { Ocean/Sea, Opera House, Pineapple, Public Services, Quicksilver, Rip } \\
\text { Curl, Skydiving/parachuting, Socceroos, Sun, Surfing }\end{array}$ \\
\hline
\end{tabular}

Table 2. Average number of components according to mapping style

\begin{tabular}{ccc}
\hline Average Number of components per participant & Type 1 & Type 2 \\
\hline Cities & 7,5 & 4,5 \\
States & 4,7 & 2,1 \\
Natural features & 1,5 & 0,9 \\
Symbols & 0,2 & 2,0 \\
Total components & 14,1 & 9,6 \\
\hline
\end{tabular}

Table 3. Place names shown on the mental maps of Australia

\begin{tabular}{lccccclcc}
\hline Cities & Type 1 & Type 2 & Cities & Type 1 & Type 2 & States & Type 1 & Type 2 \\
\hline Total & $\mathbf{2 1 1}$ & $\mathbf{1 2 6}$ & Albury & 1 & 0 & Total & $\mathbf{1 3 4}$ & $\mathbf{6 0}$ \\
Sydney & 26 & 18 & Broken Hill & 1 & 0 & Tasmania & 26 & 13 \\
Perth & 25 & 15 & Broom & 1 & 1 & Queensland & 21 & 9 \\
Melbourne & 22 & 13 & Coffs Harbour & 1 & 1 & New South Wales & 19 & 9 \\
Darwin & 20 & 15 & Geraldton & 1 & 1 & Victoria & 18 & 8 \\
Adelaide & 19 & 12 & Griffith & 1 & 1 & Northern Territories & 16 & 7 \\
Brisbane & 18 & 10 & Mandurah & 1 & 0 & Western Australia & 13 & 6 \\
Canberra & 18 & 9 & Marsfield & 1 & 0 & South Australia & 12 & 5 \\
Cairns & 12 & 10 & Port Douglas & 1 & 1 & Australian Capital Ter. & 9 & 3 \\
Alice Springs & 9 & 4 & Port Stephen & 1 & 1 & & & \\
Hobart & 9 & 4 & Townsville & 1 & 0 & Neighbouring countries & Type 1 & Type 2 \\
Gold Coast & 8 & 3 & Wagga Wagga & 1 & 0 & Total & $\mathbf{6}$ & $\mathbf{5}$ \\
New Castle & 5 & 2 & Yamba & 1 & 0 & Indonesia & 3 & 1 \\
Wollongong & 5 & 2 & Auckland & 0 & 1 & Papua New Guinea & 2 & 0 \\
Nymbin & 2 & 1 & Wellington & 0 & 1 & New Zealand & 1 & 4 \\
\hline
\end{tabular}


Table 4. Natural Features shown on the mental maps of Australia

\begin{tabular}{lccrrr}
\hline Natural Features & Type 1 & Type 2 & Natural Features & Type 1 & Type 2 \\
\hline Total & $\mathbf{4 4}$ & $\mathbf{2 7}$ & Central Coast & 1 & 1 \\
Great Australian Bite & 6 & 5 & Christmas Islands & 1 & 0 \\
Uluru-Ayers Rock & 6 & 6 & Darling River & 1 & 0 \\
Indian Ocean & 4 & 4 & Gulf of Carpenter & 1 & 1 \\
Pacific Ocean & 4 & 3 & Lake Eyre & 1 & 0 \\
Bass Strait & 2 & 1 & Lane Cove & 1 & 0 \\
Blue Mountains & 2 & 1 & Mt. Kosciuszko & 1 & 0 \\
Byron Bay & 2 & 0 & Phillip Island & 1 & 0 \\
Desert & 2 & 0 & Tasman Sea & 1 & 0 \\
Great Barrier Reef & 2 & 1 & Uranium mines & 1 & 0 \\
Hunter Valley & 2 & 2 & Capeyork Peninsula & 0 & 1 \\
Surfers Paradise & 2 & 0 & Wolfcreek & 0 & 1 \\
\hline
\end{tabular}

Table 5. Symbols shown on the mental maps of Australia

\begin{tabular}{lrrrrr}
\hline Symbols & Type 1 & Type 2 & Symbols & Type 1 & Type 2 \\
\hline Total & $\mathbf{3}$ & $\mathbf{5 7}$ & Dingo & 0 & 1 \\
Harbour Bridge & 0 & 7 & Floods & 0 & 1 \\
Opera House & 0 & 6 & Gay Couples & 0 & 1 \\
Aussi Flag & 0 & 4 & Kangaroo Island & 1 & 1 \\
Jaws/Sharks & 0 & 4 & Koala & 0 & 1 \\
Sun & 0 & 4 & Newcastle Nights & 0 & 1 \\
Surfing & 0 & 4 & Nicole Kidman & 0 & 1 \\
Boomerang & 0 & 2 & Pineapple & 0 & 1 \\
Forest & 0 & 2 & Public Services & 0 & 1 \\
Kangaroo & 0 & 2 & Quicksilver & 0 & 1 \\
Money/AUD & 0 & 2 & Rip Curl & 0 & 1 \\
Ocean / Sea & 1 & 2 & Skydiving/parachuting & 0 & 1 \\
Aboriginal Flag & 0 & 1 & Socceroos & 0 & 1 \\
Aborigines & 0 & 1 & Train Line & 0 & 1 \\
Apple & 0 & 1 & Grape & 1 & 0 \\
\hline
\end{tabular}




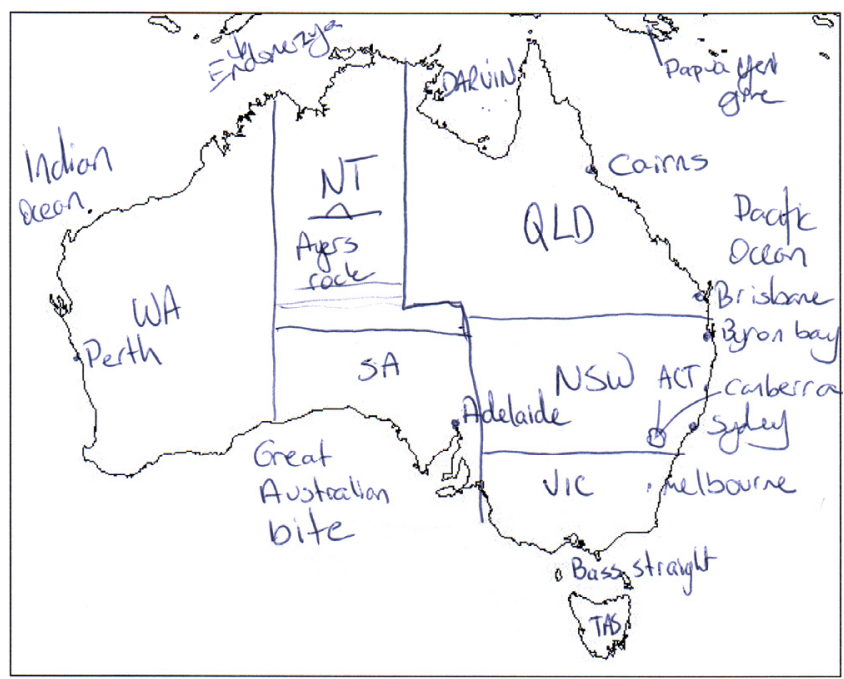

Figure 3. An outline map filled by a participant with place names and state borders

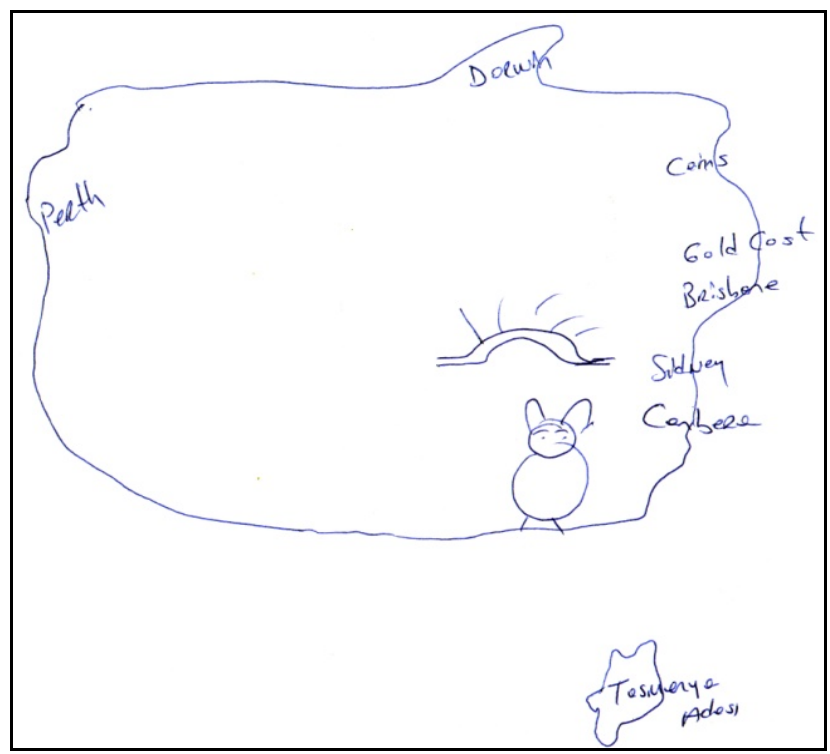

Figure 4. An imaginary map including the most striking symbols of Australia: A kangaroo and the Ayers Rock 


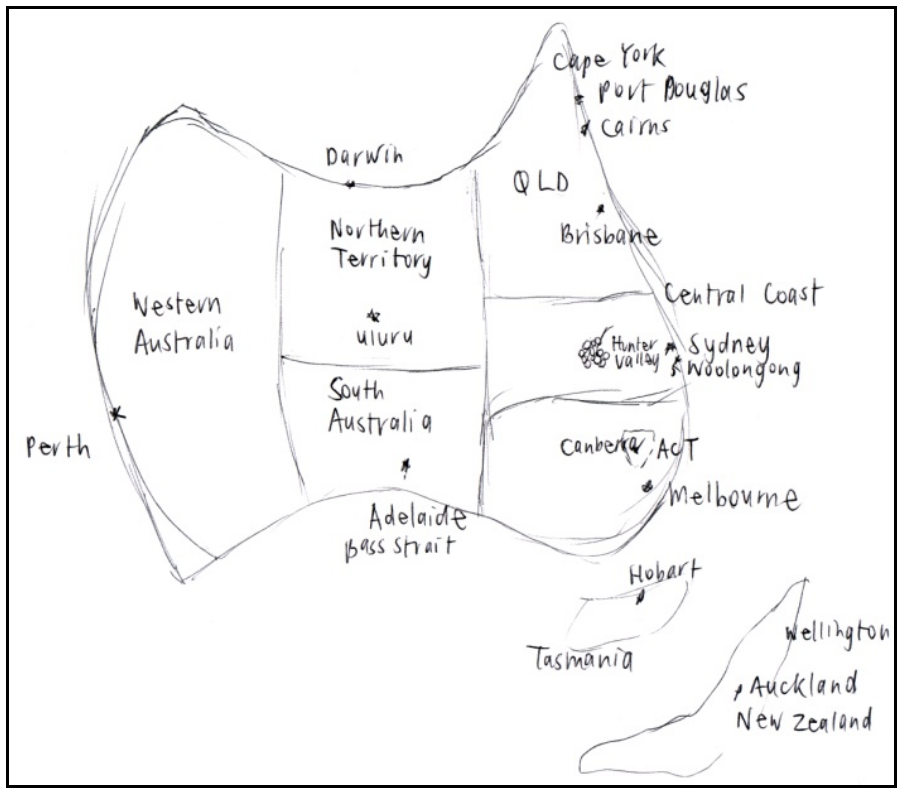

Figure 5. An imaginary map of Australia in graphical style

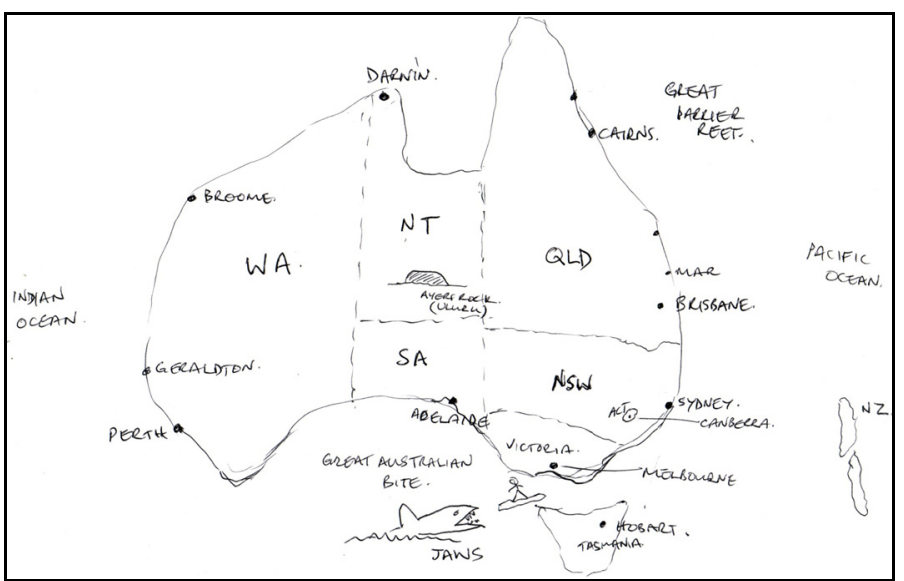

Figure 6. A graphical style map of Australia with symbolic elements

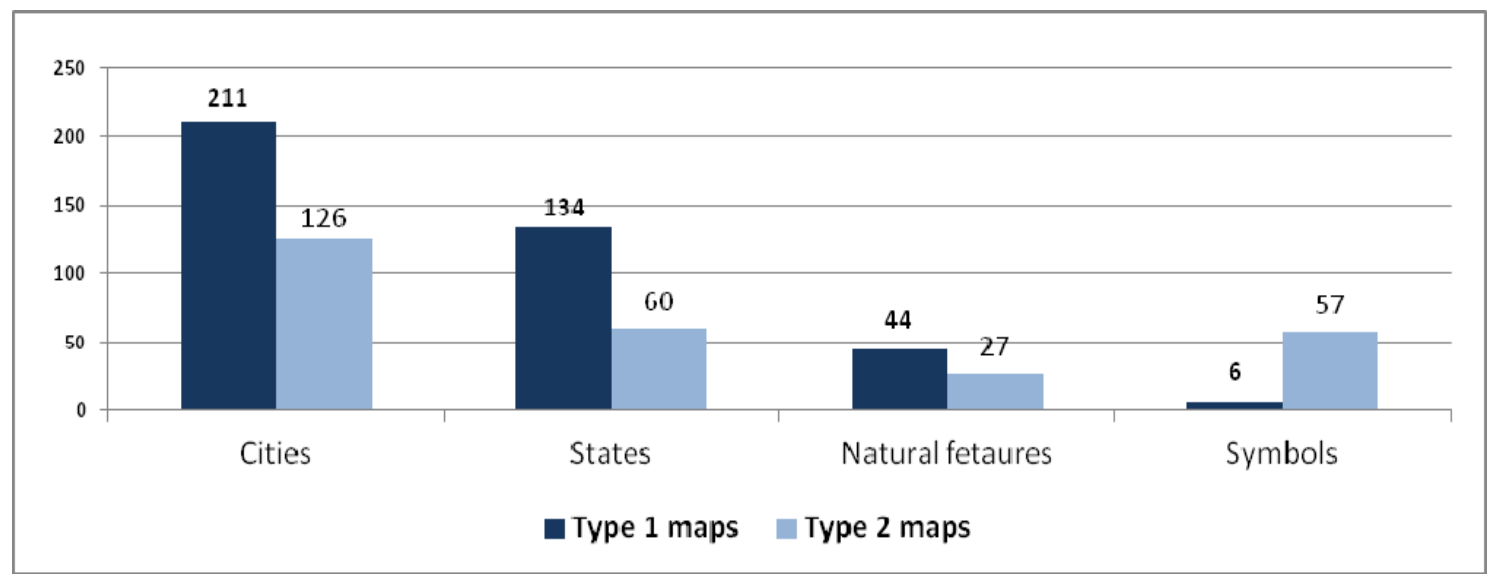

Figure 7. Number of the components according to mapping style 


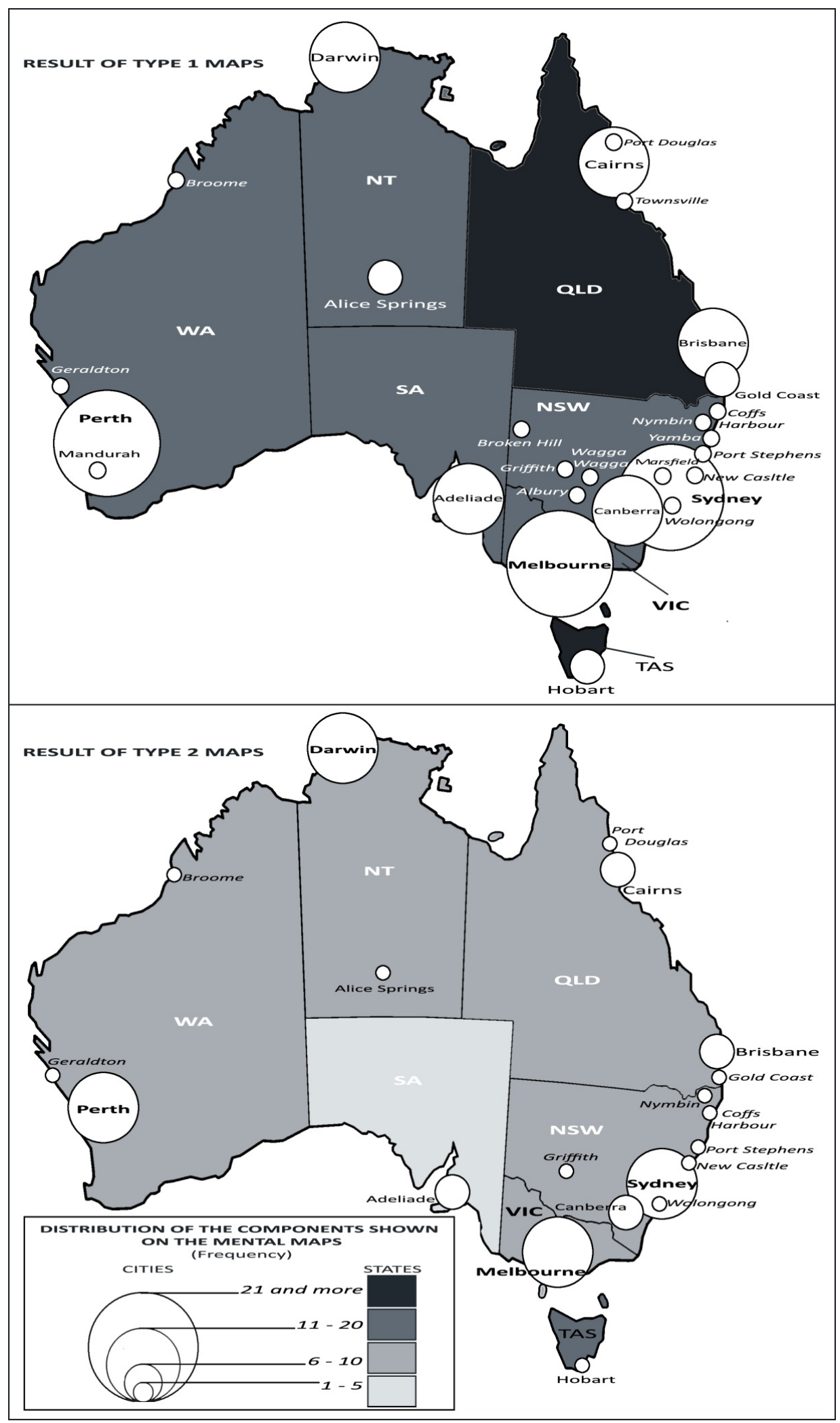

Figure 8. Distribution of the place names shown on the mental maps of Australia according to technique of mental mapping 
Table 6. Connotations about Australia

\begin{tabular}{|c|c|c|}
\hline CONNOTATION GROUPS & $\%$ & \\
\hline Natural characteristics & 39,3 & $\begin{array}{l}\text { kangaroo (15), koala (13), beach (7), big continent (4), desert (4), } \\
\text { forests (4), island (4), nice weather (4), ocean/sea (4), sand (4), sun } \\
\text { (4), dingo (3), nature (3), Uluru-Ayers rock (2), distance (2), } \\
\text { Tasmanian devil (1), weird animals (1), wildlife (1) }\end{array}$ \\
\hline Cultural symbols & 24,8 & $\begin{array}{l}\text { Opera House (21), Harbour Bridge (16), Aborigines (9), } \\
\text { didgeridoo (2), Coopers (1), Nicole Kidman (1), slippers (1), Steve } \\
\text { Irvin (1) }\end{array}$ \\
\hline Connotations on lifestyle & 14,8 & $\begin{array}{l}\text { surf (6), BBQ (3), nightlife/girls (3), rugby (3), polite people (2), } \\
\text { peace (2), gay rights (2), v.b. beer (2) home (2), friendship (1), love } \\
\text { (1), fishing (1), freedom (1), holiday village of the world (1,) safe } \\
\text { life (1), fixed working hours (1) }\end{array}$ \\
\hline Place names & 14,4 & $\begin{array}{l}\text { Sydney (23), Melbourne (3), Marshfield (1), Nimbin (1), } \\
\text { Queensland (1), Darling harbour (1) }\end{array}$ \\
\hline Political and economic elements & 6,7 & $\begin{array}{l}\text { UK/England (3), hidden nationalism (2), J. Assange (2), ANZAC } \\
\text { (1), educational market (1), flag (1), living standards (1), money } \\
\text { (1), multicultural (1) }\end{array}$ \\
\hline
\end{tabular}

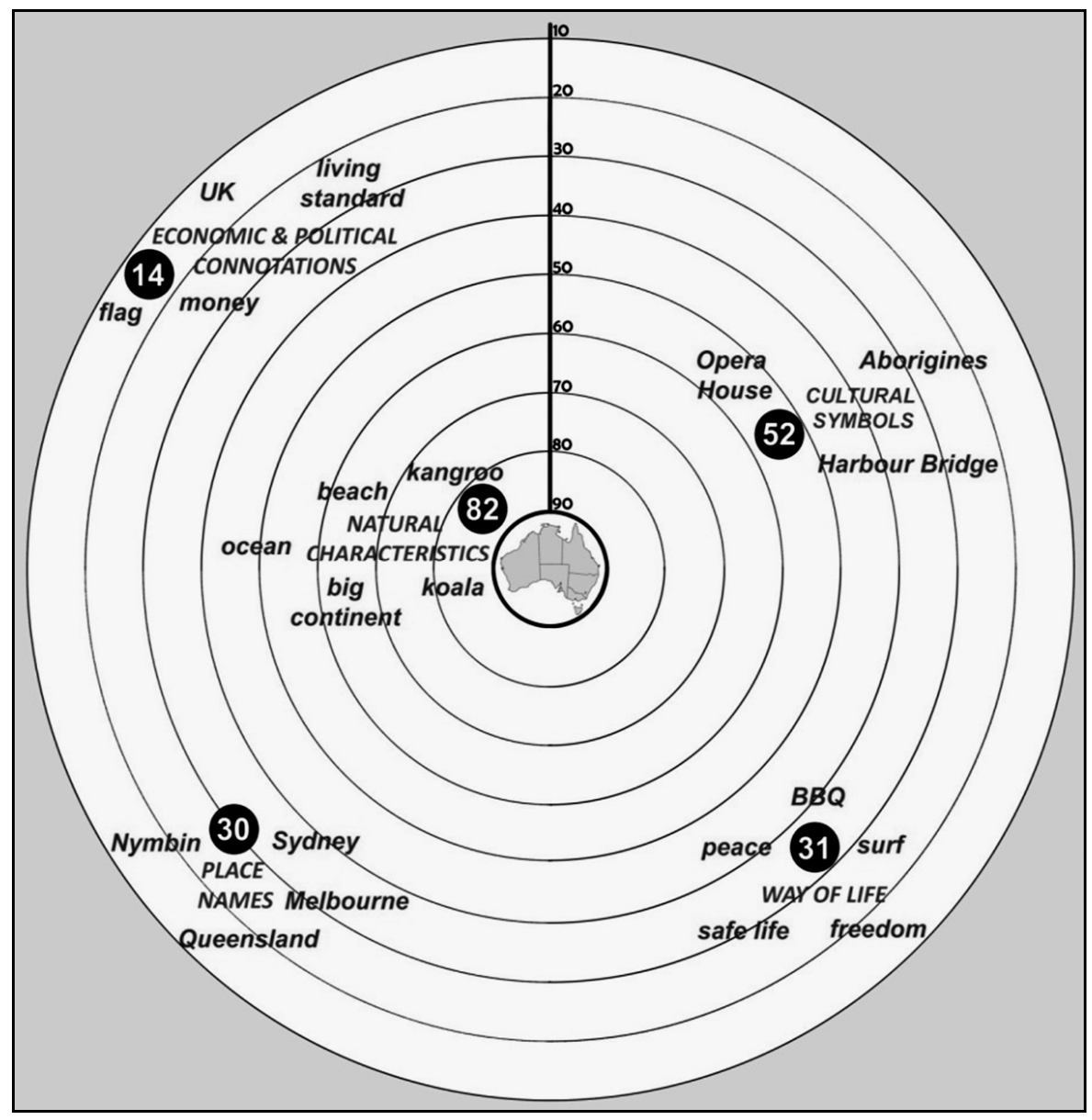

Figure 9. A constellation of connotations about Australia (frequency) 


\section{Conclusion}

However Australia is "a European country in the wrong hemisphere" as Fisher and Sonn claims, and a part of the western world; it is perceived very differently from the main "Europe"; as Paassi (2001) indicated "Europe" is seen mostly as a structural body and represented mostly in aspect of its political-institutional characteristics which is denoted as "the European Union" as a political and economic power. Australia on the other hand, as our findings indicate, is represented mostly by its natural and geographical characteristics rather than its political-institutional structure. This is especially related to the isolated geographical location of this continent. Nature has been a very strong dimension of representations of Australia, for example, Tada (2000:170) focusing on the representation of Australia in media, states that the specific foci of representations of Australia include natural sources, tourism and an atmosphere of freedom, each of which has a link to Australia's natural environment. Özgüç (1999:114) also emphasises that a mental map of Australia is based on an image including mostly natural characteristics of the continent such as the central dry, red land and unique fauna. In our study, particularly the connotations of Australia indicate the image of the continent as a place coded with its natural characteristics.

Curtis and Fotheringham (1995:86) in their work focusing on how large scale spatial information surfaces are constructed and how this construction varies according to an individual's location in case of USA, state that spatial information acquisition and recall is positively related to population size and to the designation of a city as a state capital. Spatial information (place names) from the mental mapping data from Australia also indicate a similar result, with high intensification of cities which are highly populated ad mostly the state capitals of the continent.

Regarding the mapping technique, it is seen that freely drawn mental maps are more imaginary, symbolic and subjective than the filled-in outline maps. Therefore, it can be suggested that imaginary maps (Type 2) may lead us to understand the place-related experiences of people and how they perceive a region better than the formal representations and boundaries which are reflected more in the outline maps (Type 1). On the other hand, using blank maps in cognitive map studies may lead to derive richer maps because it seems that the formal boundaries have an evocative function in recognizing and reflecting the spatial images. As it is seen in this case, filled-in outline maps are richer than the imaginary maps in aspect of the number of the components shown by the participants. In other words, spatial representation of a place may become more formal, objective and realistic when a directing element is utilized which here is the continental boundary.

\section{References}

Australian Bureau of Statistic (ABS). Retrieved from www.abs.gov.au

Berkowitz, C., Saarinen T. F., \& MacCabe, C. L. (1992) The World Image of Africa. In A. D. Hill (Ed.), Interdependence in Education (pp. 15-16).

Bilgin, N. (1995). Sosyal psikolojide yöntem ve pratik çalı̧malar. Sistem Yayıncıllk, İstanbul.

Clark, J. R. (1977). Turkish Cologne: the mental maps of migrant workers in a German city. Department of Geography, University of Michigan.

Clark, M. (2006). A short history of Australia. Penguin UK.

Curtis, A., \& Fotheringham, A. S. (1995). Large-scale information surfaces: an analysis of city-name recalls in the United States. Geoforum, 26(1), 75-87. http://dx.doi.org/10.1016/0016-7185(95)00014-C

Eden, C. (2004). Analyzing cognitive maps to help structure issues or problems. European Journal of Operational Research, 159(3), 673-686. http://dx.doi.org/10.1016/S0377-2217(03)00431-4

Fisher, A. T., \& Sonn, C. C. (2002). Psychological sense of community in Australia and the challenges of change. Journal of Community Psychology, 30(6), 597-609. http://dx.doi.org/10.1002/jcop.10029

Fuller, G., \& Chapman, M. (1974). On the role of mental maps in migration research. International Migration Review, 491-506. http://dx.doi.org/10.2307/3002201

Gold, J. R. (2009). Behavioural Geography. In R. Kitchin \& N. Thrift (Eds.), International Encyclopaedia of Human Geography, 282-293. Amsterdam: Elsevier. http://dx.doi.org/10.1016/B978-008044910-4.00665-9

Göregenli, M. (1985). Kentsel Alanlartn Algllanması ve Kentsel Imajlar (Unpublished Master thesis). Ege University Institute of Social Sciences, Izmir.

Göregenli, M. (2013). Çevre Psikolojisi: İnsan-Mekân İlişkileri. İstanbul Bilgi Üniversitesi.

Gould, P., \& White, R. (1986, 2002). Mental Maps. London: Routledge 
Milgram, S. (1972). A Psychological Map of New York City. American Scientist, 60, 194-204.

Murphy, A. B., Jordan-Bychkov, T. G., \& Bychkova-Jordan, B. (2009). The European Culture Area: A Systematic Geography. Rowman \& Littlefield Publishers Lanham.

Orleans, P. (1973). Differential Cognition of Urban Residents: Effects of social Scale on Mapping. In R. M. Downs \& D. Stea (Eds.), Image and Environment: Cognitive Mapping and Spatial Behaviour (pp. 115-130). Chicago: Aldin Publishing Company.

Özgüç, N. (1998) Avustralya, Yeni Zelanda ve Pasifik Adaları [Australia, New Zeeland and Pacific Islands]. Istanbul: Çantay Kitabevi (in Turkish).

Paasi, A. (2001). Europe as social process and discourse. European Urban and Regional Studies, 8, 7-28. http://dx.doi.org/10.1177/096977640100800102

Saarinen, T. F. (1987). Centring of Mental Maps of the World. Discussion Paper, Department of Geography and Regional Development, Arizona.

Südaş, İ., \& Göregenli, C. (2012). Cognitive Maps of Europe: Geographical Knowledge of Turkish Geography Students. European Journal of Geography, 3(1), 41-56.

Südaş, İ., \& Göregenli, M. (2013). Europe in Mind: Social Representations of Turkey-Europe Relations in Case of Turkish University Students. European Journal of Geography, 4(1), 34-45.

Tada, M. (2000). Japanese newspaper representations of Australia 1970-1996. Journal of Australian Studies, 24(66), 169-179. http://dx.doi.org/10.1080/14443050009387622

\section{Copyrights}

Copyright for this article is retained by the author(s), with first publication rights granted to the journal.

This is an open-access article distributed under the terms and conditions of the Creative Commons Attribution license (http://creativecommons.org/licenses/by/3.0/). 